\begin{tabular}{|c|c|}
\hline $\begin{array}{l}\text { EXCELLENT } \\
\text { PUBLISHERS }\end{array}$ & $\begin{array}{c}\text { International Journal of Current Research in } \\
\text { Biosciences and Plant Biology } \\
\text { ISSN: 2349-8080 (Online) } \bullet \text { Volume } 3 \bullet \text { Number } 10 \text { (October-2016) }\end{array}$ \\
\hline
\end{tabular}

\title{
High Tunnel Production of Cucumber (Cucumis sativus L.) as Influenced by Apical Clipping in Iwollo, South Eastern Nigeria
}

\author{
O. G. Nwankwo ${ }^{*}$, J. O. Adinde ${ }^{2}$, U. J. Anieke', C. M. Ukwuani3 ${ }^{3}$ P. O. Ugwuanyi ${ }^{1}$ \\ and A. C. Aniakor 4 \\ ${ }^{1}$ Department of General Studies, Enugu State Polytechnic, Iwollo, Enugu State, Nigeria \\ ${ }^{2}$ Department of Horticultural Technology, Enugu State Polytechnic, Iwollo, Enugu State, Nigeria \\ 3 Department of Fishery Technology, Enugu State Polytechnic, Iwollo, Enugu State, Nigeria \\ 4Department of Agricultural Technology, Enugu State Polytechnic, Iwollo, Enugu State, Nigeria
}

*Corresponding author.

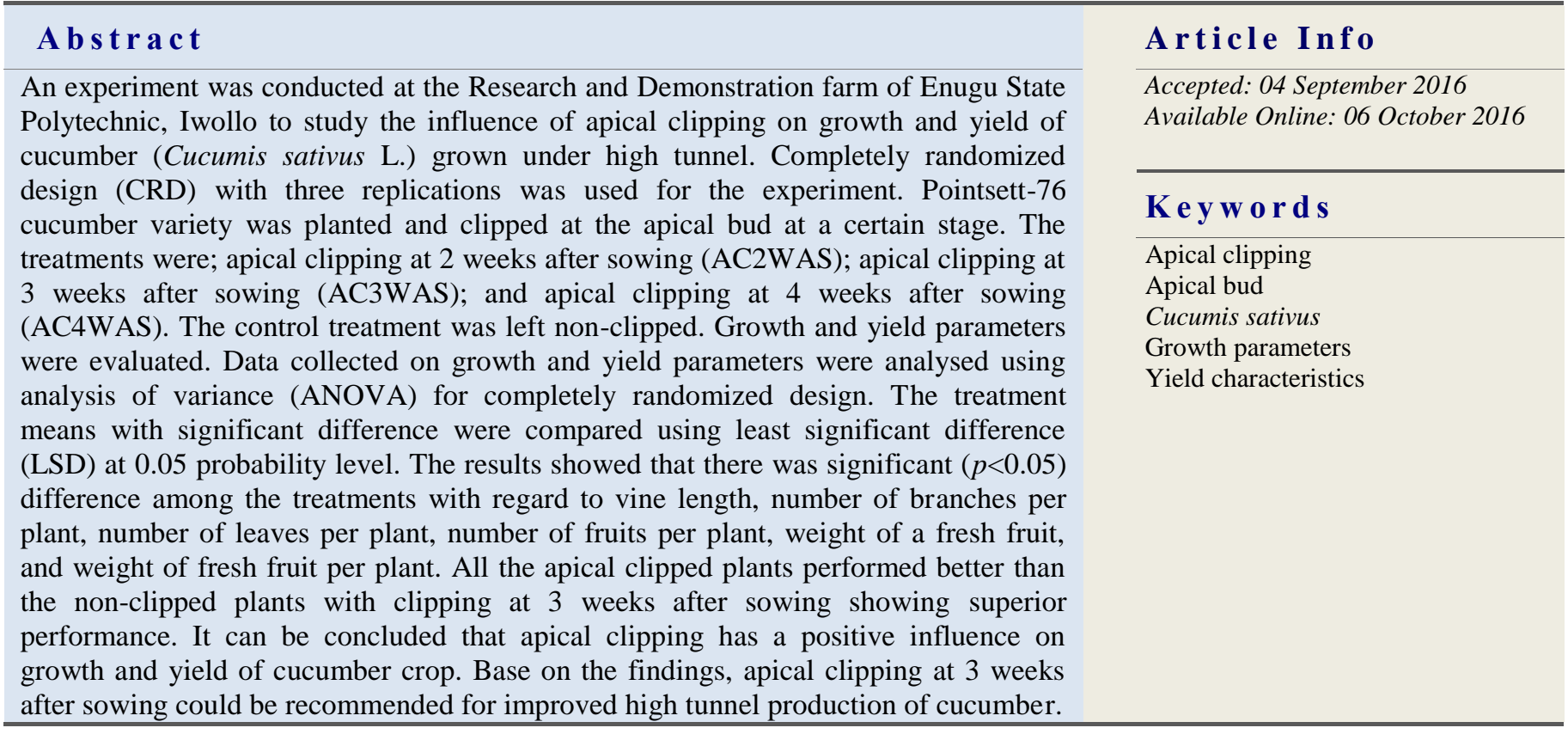

\section{Introduction}

Cucumbers are cylindrical fruits, elongated with tapered ends, used as culinary vegetables, scientifically known as Cucumis sativus $\mathrm{L}$. and belong to the same botanical family as melons (watermelon and cantaloupe) and squashes (summer squash, winter squash, zucchini and pumpkin). Cucumber is one of the monoecious annual crops in the Cucurbitaceae family that has been cultivated by man for over 3,000 years (Adetula and Denton, 2003; Okonmah, 2011). It originated in India, spread westward and became popular throughout the Egyptain and the Greek-Roman Empire (Renner et al., 2007). It is an important vegetable crop grown in the temperate and tropical zones of the world. With respect to economic importance, it ranks fourth after tomatoes, 
cabbage and onion in Asia (Eifediyi and Remison, 2011), and second after tomato in Western Europe (Phu, 1997). Soft and succulent, the vegetable crop is cherished by man and eaten in salads or sliced into stew in tropical regions. Its juice is often recommended as source of silicon to improve the health and complexion of the skin (Duke, 1997). Cucumber is a very good source of vitamins $\mathrm{A}, \mathrm{C}, \mathrm{K}, \mathrm{B} 6$, potassium, pantothenic acid, magnesium, phosphorus, copper, manganese, fibre, and antioxidants (Vimala et al., 1999). It helps in healing diseases of urinary bladder and kidney; digestive problems like heartburn, acidity, gastritis and ulcer (Garcia-Closas et al., 2004). The ascorbic acid and caffeic acid contained in cucumber help to reduce skin irritation and swelling (Okonmah, 2011).

Cucumber can be grown in greenhouses or outdoors in the garden or in the field. It requires a stable warm temperature for good yield (Cobeil and Gosselin, 1990). One of the problems associated with cucumber production in southeastern Nigeria is high disease infestation associated to high rainfall and high humid conditions in the zone. High tunnel is a greenhouse- like structure whereby plants are grown utilizing the soil (Wells and Loy, 1993). According to Lewis (2014), high tunnels are low-cost season-extension technology used for producing a diversity of horticulture crops including vegetables, fruits, herbs and flowers. Specifically, high tunnels are passively vented, solar greenhouses covered with 1-2 layers of greenhouse plastic. It is considered to be a less expensive alternative to a true greenhouse and yet can provide some control of environmental factors that affect plant growth and yield. Such control is due to protection against wind, rain, weeds and some insects and diseases. Apical clipping has been reported by many researchers to improve growth and yield of various crops. Apical clipping is the removal of top shoot (apical meristem) of a plant to induce lateral branches (Khan et al., 1993; Kokilavani et al., 2007). It is the same with nipping, pinching, or topping. Auxins from the shoot apex are believed to inhibit the growth of lateral buds through the method called direct inhibition hypothesis (Campbell et al., 2008). When the apical bud is removed, the apical dominance of auxin is removed thereby removing the inhibitory effect on cytokinin which thus, initiates lateral buds into branches (Campbell et al., 2008; Adinde et al., 2016). Apical clipping has been reported to increase lateral branches (Cline, 1994; Adinde et al., 2016), increase number of fruits and yield (Adinde et al., 2016); and produce desirable fruit size (Khan et al., 1993; Singh and Diwakar, 1995). Chaube and Pundhir (2005) reported that chickpea nipping after
45 days of sowing increased yield as well as controlled disease severity. Adinde et al. (2016) reported that nipping significantly improved growth and yield of green pepper with nipping at 2 weeks after transplanting having superior values. The objective of this study was to determine the influence of apical clipping on growth and yield of cucumber grown under high tunnel in Iwollo, southeastern Nigeria.

\section{Materials and methods}

\section{The study area}

The study was carried out under high tunnel at the Research and Demonstration Farm of Enugu State Polytechnic, Iwollo in February, 2016. The study area is located in southeast agro-ecological zone of Nigeria with geographical co-ordinate of $\mathrm{N}^{0} 27^{\mathrm{I}} 0^{\mathrm{II}}, \quad \mathrm{E} 7^{0} 17^{\mathrm{I}} 0^{\mathrm{II}}$ (Maplandia, 2016). The rainfall pattern is bimodal; between April-June and September- November with short spell in August (Uguru, 2011).

\section{High tunnel construction}

A high tunnel of $7 \mathrm{~m}$ high, $5 \mathrm{~m}$ wide and $9 \mathrm{~m}$ long was constructed using bamboo sticks. The high tunnel was covered with a polyethylene film suitable for greenhouses.

\section{Soil sampling}

Composite soil sample was taken from the soil used for the experiment and analysed for physical and chemical properties using the procedure described by Okalebo et al. (2006).

\section{Experimental design and treatments}

The experiment was laid out in Completely Randomized Design (CRD) comprising four treatments with four replications. The treatments evaluated were:

Apical clipping at 2 weeks after sowing (AC2WAS) Apical clipping at 3 weeks after sowing (AC3WAS) Apical clipping at 4 weeks after sowing (AC4WAS) No clipping (NC) (Control)

\section{Procedure}

The experiment was carried out in a high tunnel under closed production system. Cucumber seeds cultivar Pointsett-76 was planted in a single row at the rate of 2 
seeds per hill and $2 \mathrm{~cm}$ depth using a spacing of $0.5 \mathrm{~m}$ $(50 \mathrm{~cm})$ between hills. The seeds were sown inside wooden boxes of $25 \mathrm{~cm}$ high, $150 \mathrm{~cm}$ long and $50 \mathrm{~cm}$ wide filled with top soil. Each box contained four stands. Four boxes were used to replicate each treatment. Poultry droppings at the rate of 15 tons $\mathrm{ha}^{-1}$ was incorporated into the soil and watered one week before sowing to allow for mineralization. The seedlings were thinned down to one stand per hill before 3 true leaf stage. The plants were watered as required using watering can. Weeding was done manually by hand picking. Pest was controlled using Attackee insecticide (Lamda cyhalothrin) and fungal disease was controlled using Redforce fungicide (Metalaxyl-M 6\% + Copper (I) oxide $60 \%$ WP). Apical clipping was done on the plants by removing the apical bud of the plants.

\section{Data collection}

Data were collected on growth and yield parameters from 2 sample plants for each replication. Data on vine length, number of leaves per plant, and number of branches per plant were collected six weeks after planting. Data on number of fresh fruits per plant, weight of a fresh fruit and fresh fruit weight per plant were collected upon harvesting from 7 weeks after planting.

\section{Number of branches per plant}

Number of branches per plant was determined by direct counting of all the branches on the sample plants and dividing by number of the sample plants.

No. of branches per plant $=\frac{\text { Total no. of branches on the sample plants }}{\text { No. of sample plants }}$

\section{Vine length $(\mathrm{cm})$}

Vine length was measured using measuring tape starting from the base to the tip of the plant.

\section{Number of leaves per plant}

Number of leaves per plant was determined by direct counting of all the leaves on the sample plants and dividing by number of the sample plants.

No. of leaves per plant $=\frac{\text { Total no. of leaves on the sample plants }}{\text { No. of sample plants }}$

\section{Number of fresh fruit per plant}

Number of fresh fruit per plant was determined by counting the number of all harvested fresh fruits from the sample plants and dividing by the number of sample plants.

No. of fruits per plant $=\frac{\text { Total no. of fruits harvested from the sample plants }}{\text { No. of sample plants }}$

\section{Weight of a fresh fruit (g)}

Weight of a fresh fruit was calculated by dividing the total weight of the harvested fresh fruits by the total number of fresh fruits.

$$
\text { Wt. of a fresh fruit }(\mathrm{g})=\frac{\text { Total wt. of fresh fruits weighed }}{\text { Total no. of fresh fruits weighed }}
$$

\section{Fresh fruit weight per plant (kg)}

Fresh fruit weight per plant was determined by multiplying the weight of a fresh fruit by the number of fresh fruit per plant. Thus,

Fresh fruit weight per plant $(\mathrm{kg})=$ weight of a fresh fruit $(\mathrm{kg}) \times$ number of fresh fruit per plant

\section{Statistical analysis}

All the data collected was subjected to statistical analysis of variance (ANOVA) for completely randomized design (CRD) to test for significance of treatment effects using Genstat Release 10.3DE software (GenStat, 2011). Treatment means were separated using least significant difference (LSD) at 0.05 probability level.

\section{Results}

\section{Pre-planting soil properties}

Pre-planting soil properties were presented in Table 1. The result showed that the soil belonged to sandy loam textural class. The $\mathrm{pH}$ of 5.6 of the soil was within the range favourable for vegetable cropping (Tindal, 1983).

\section{Vegetative Growth of Cucumber (Cucumis sativus) as influenced by apical clipping}

Results of the analysis of variance as shown in Table 2 showed that apical clipping significantly $(p<0.05)$ influenced vine length, number of branches per plant and 
number of leaves per plant. Vine length showed significant variation $(p<0.05)$ among the treatments. The highest vine length of $121.2 \mathrm{~cm}$ was obtained in control (NC) and the least $(60.5 \mathrm{~cm})$ in apical clipping at 2 weeks after sowing (AC2WAS). Consequently, all the clipping treatments induced significantly $(p<0.05)$ higher number of branches per plant compared to control (NC). The highest number of branches (7.45) was obtained in apical clipping at 3 weeks after sowing (AC3WAS) while the least (4.25) was obtained in control (NC). The mean number of branches (6.25) obtained in plants clipped at 2 weeks after sowing was statistically at par with 5.75 branches obtained in plants clipped at 4 weeks after sowing (AC4WAS). Similarly, number of leaves per plant was significantly higher in apical clipping treatments compared to control and followed the same trend with number of branches per plant. The highest number of leaves (60) was obtained in apical clipping at 3 weeks after sowing (AC3WAS) while the least (39.75) was obtained in control (NC). The mean number of leaves (54) obtained in plants clipped at 2 weeks after sowing (AC2WAS) was statistically at par with 49.5 leaves obtained in plants clipped at 4 weeks after sowing (AC4WAS).

Table 1. Properties of the soil used for the experiment.

\begin{tabular}{ll}
\hline Soil properties & Values \\
\hline Physical properties (\%) & \\
Clay & 20.82 \\
Sand & 62.50 \\
Silt & 16.68 \\
Textural class & Sandy loam \\
Chemical properties & \\
Phosphorus $\left(\mathrm{ppm}^{\mathrm{O}}\right)$ & 18.57 \\
Organic carbon $\left(\mathrm{g} \mathrm{kg}^{-1}\right)$ & 2.20 \\
Soil pH $\left(\mathrm{H}_{2} \mathrm{O}\right) /\left(\mathrm{KCl}^{-1}\right)$ & $5.6 / 5.1$ \\
Nitrogen $\left(\mathrm{g} \mathrm{kg}^{-1}\right)$ & 0.024 \\
Exchangeable cations $(\mathbf{m e q} / \mathbf{1 0 0 g}$ soil) & \\
Potassium & 0.36 \\
Magnesium & 2.62 \\
Calcium & 2.78 \\
Sodium & 2.84 \\
\hline
\end{tabular}

Table 2. Growth parameters of cucumber (Cucumis sativus) as influenced by apical clipping.

\begin{tabular}{llll}
\hline Treatments & Vine length $(\mathbf{c m})$ & No. of branches per plant & No. of leaves per plant \\
\hline AC2WAS & $60.5^{\mathrm{d}}$ & $6.25^{\mathrm{b}}$ & $54.0^{\mathrm{b}}$ \\
AC3WAS & $82.2^{\mathrm{c}}$ & $7.45^{\mathrm{a}}$ & $60.0^{\mathrm{a}}$ \\
AC4WAS & $102.5^{\mathrm{b}}$ & $5.75^{\mathrm{b}}$ & $49.5^{\mathrm{b}}$ \\
NC (control) & $121.2^{\mathrm{a}}$ & $4.25^{\mathrm{c}}$ & $39.75^{\mathrm{c}}$ \\
$L S D_{0.05}$ & 9.96 & 0.781 & 4.785 \\
$S . E$. & 6.46 & 0.507 & 3.106 \\
$C V(\%)$ & 7.1 & 8.6 & 6.1 \\
\hline
\end{tabular}

AC =Apical Clipping; WAS = Weeks After Sowing; NC = No clipping; LSD = Least significant difference; S. E. = Standard error; $\mathrm{CV}=$ Coefficient of variation. Mean values within the same column with the same letter are not significantly different $(p>0.05)$.

Table 3. Yield parameters of cucumber (Cucumis sativus) as influenced by apical clipping.

\begin{tabular}{llll}
\hline Treatments & Number of fruit per plant & Weight of a fresh fruit (g) & $\begin{array}{l}\text { Fresh fruit weight per } \\
\text { plant (kg) }\end{array}$ \\
\hline AC2WAS & $5.1^{\mathrm{a}}$ & 226.8 & $1.156^{\mathrm{b}}$ \\
AC3WAS & $5.575^{\mathrm{a}}$ & 247.7 & $1.377^{\mathrm{a}}$ \\
AC4WAS & $4.175^{\mathrm{b}}$ & 245.1 & $1.021^{\mathrm{b}}$ \\
$\mathrm{NC}($ control) & $2.575^{\mathrm{c}}$ & 261.9 & $0.633^{\mathrm{c}}$ \\
$L S D_{0.05}$ & 0.5379 & $N$ & 0.1505 \\
$S . E$. & 19.11 & 0.0977 \\
$C V(\%)$ & 7.3491 & 9.3 \\
\hline AC =Apical Clipping; WAS = Weeks After Sowing; NC = No clipping; LSD = Least significant difference; NS= Non \\
significant; S. E. = Standard error; CV = Coefficient of variation. Mean values within the same column with the same letter are \\
not significantly different $(p>0.05)$.
\end{tabular}

\section{Yield of cucumber (Cucumis sativus) as influenced by apical clipping}

Results of the analysis of variance as shown in Table 3 showed that apical clipping significantly $(p<0.05)$ influenced number of fresh fruit per plant and fresh fruit weight per plant. There was no significant difference $(p>0.05)$ in weight of a fresh fruit among the treatments. All the clipping treatments induced higher number of fresh fruit per plant and fresh fruit weight per plant 
compared to control (NC). The highest mean number of fresh fruit (5.575) obtained in AC3WAS was statistically at par with 5.1 fresh fruits obtained in AC2WAS. Similarly, highest fresh fruit weight $(1.377 \mathrm{~kg}$ per plant) was obtained in AC3WAS and the least $(0.633 \mathrm{~kg}$ per plant) in control (NC). Fresh fruit weight obtained in AC2WAS (1.156kg per plant) was statistically at par with the value obtained in AC4WAS (1.021kg per plant).

\section{Discussion}

The findings as presented in Table 2 and Table 3 showed that growth and yield parameters of cucumber grown under high tunnel were influenced by apical clipping. The results showed significant $(p<0.05)$ variations in growth and yield of cucumber among the treatments. The vine length as shown in Table 2 increased significantly with increase in weeks after sowing before clipping and highest at non clipped plants. This could be attributed to the longer activity of IAA (indole acetic acid) - growth hormone at the apical bud before it was removed through apical clipping. The reduced vine length obtained in apical clipped plants as compared to the non-clipped plants could be attributed to the removal of the growth hormone (Indole Acetic Acid) at the apical bud through clipping which probably reduced the apical dominance of auxin. Similar results were obtained by Korla and Sani (2003) on fenugreek; Adinde et al. (2016) on green pepper. Apical clipping also, significantly $(p<0.05)$ influenced the number of branches per plant and number of leaves per plant as shown in Table 2. This conforms to the findings of Korla and Sani (2003) on fenugreek, Venkadachalam (2003) on sesame, and Adinde et al. (2016) on green pepper.

The significant increase in the number of branches obtained in clipped plants could be attributed to the removal of the apical bud which reduced apical dominance of auxin and initiated formation of lateral buds and subsequently lateral branches. When the apical bud is removed, the apical dominance of auxin is removed thereby removing the inhibitory effect on cytokinin which thus, initiates lateral buds into branches (Campbell et al., 2008; Adinde et al., 2016). Moreover, the utilization of photosynthates in apical clipped crops for the production of lateral branches was probably higher and might also have contributed to the increase in number of branches per plant on clipped plants over control. Number of leaves per plant followed the same trend with number of branches per plant. The higher number of leaves obtained in clipped plants could be due to more number of branches. This result is in accordance with the work of Imayavaramban et al. (2004), and Kokilavani et al. (2007) on sesame and Adinde et al. (2016) on green pepper.

Apical clipping at 3 weeks after sowing showed superior value over other clipping treatments. At 2 weeks after sowing, the cucumber stands probably were not fully established and possibly experienced shock as a result of clipping. Flower initiation in pointsett-76 cucumber variety starts from 5 weeks after sowing and marks the beginning of reproductive phase of the crop. Plants clipped at 4 weeks after sowing probably were close to the reproductive phase and probably did not have enough time to manifest the effect of clipping on vegetative growth as much as those clipped at 3 weeks after sowing. This possibly explained the superior vegetative growth obtained in clipping at 3 weeks after sowing over clipping at 4 weeks after sowing. The findings of Chaube and Pundhir (2005); and Adinde et al. (2016) lend support to this result. Apical clipping significantly $(p<0.05)$ influenced number of fresh fruit per plant and fresh fruit weight per plant as presented in Table 3. All the clipped plants performed better than the control. The improved yield obtained in clipped plants could be due to induction of more number of lateral branches and leaves. The apical clipping might have efficiently altered the crop architecture, which in turn increased the lateral branches and leaves that led to greater chance for development of source and sink features in cucumber. More branches probably induced more leaves and more flower buds. High number of flower buds increases the chances of more fruits being produced by plants. High number of leaves is an indication of high photosynthate. Superior yield obtained in 3 weeks after sowing over other apical clipping treatments and control could be attributed to induction of superior branches and leaves. The beneficial impacts of clipping on yield attributes of crops were reported by Cobeil and Gosselin (1990) on cucumber, Khan et al.(1993) on rapeseed, Singh and Diwakar (1995), Chaube and Pundhir (2005), Baloch and Zubir (2013) on chickpea; Imayavaramban et al. (2004) and Kokilavani et al. (2007) on sesame; and Adinde et al. (2016) on green pepper.

\section{Conclusion}

The results of the study showed that apical clipped plants performed better than the non-clipped plants in terms of number of branches, number of leaves and yield with plants clipped at 3 weeks after sowing having superior performances. It could be concluded that apical clipping positively influenced growth and yield of cucumber. 
Apical clipping at 3 weeks after sowing could therefore be recommended for improved high tunnel production of cucumber in Iwollo, south-eastern Nigeria.

\section{Conflict of interest statement}

Authors declare that they have no conflict of interest.

\section{References}

Adetula, O., Denton, L., 2003. Performance of vegetative and yield accessions of cucumber (Cucumis sativa L.) Horticultural Society of Nigeria (HORTSON) Proceedings of $21^{\text {st }}$ Annual Conference. pp.10-13.

Adinde, J. O., Uche, O. J., Anieke, U. J., Ukwuani, C. M., Agu, C. J., Nwankwo, O. G., Ugwuanyi, P. O., 2016. Effect of nipping on growth and yield of green bell pepper (Capsicum annuum L. $c v$ goliath) in Iwollo, south-eastern Nigeria. Int. J. Sci. Nature. 7(2), 423-428.

Baloch, M. S., Zubir, M., 2010. Effect of Nipping on growth and yield of Chickpea. J. Anim. Plant Sci. 20(3), 208-210.

Campbell, N. A., Reece, J. B., Urry, L. A., Cain, M. L., Wasserman, S. A., Minorsky, P. V., Jackson, R. B., 2008. Biology. $8^{\text {th }}$ Edn. Pearson Benjamin Cumming, San Francisco and London. pp.827-830.

Chaube, H., Pundhir, V. S., 2005. Crop Diseases and their Management. Prentice Hall of India (Pvt. Ltd), New Delhi.

Cline, M., 1994. The role of hormone in apical dominance, new approval to an old problem in plant development. Physiol. Plant. 90, 230-237.

Cobeil, G., Gosselin, A., 1990. Influence of pruning and season on productivity of cucumber plants grown in a sequence cropping system. Sci. Hortic. 41(3), 189-200.

Duke, J., 1997. The Green Pharmacy. St. Martins Press, New York.

Eifediyi, E. K., Remison, S. U., 2010. Growth and yield of cucumber (Cucumis sativum L.) as influenced by farm yard manure and inorganic fertilizer. J. Plant Breed. Crop Sci. 2(7), 216-220.

Garcia-closes, R., Berenguer, A., Sanchez, M. J., 2004. Dietary sources of vitamins C, vitamins E and specific cartenoids in Spain. British J. Nutr. 91, 1005-1011.

GenStat Release 10.3DE., 2011. Discovery Edition 4 VSN International Ltd. Rothamsted Experimental Station, Howel, Hempstead, UK.

Imayavaramban, V., Pannerselvam, P., Isaac Manuel R., Thabuthan, K., 2004. Effect of different nitrogen levels, chippings and growth regulators on the growth and yield of sesame. Sesame Safflower Newslett. 19, 40-44.

Khan, R. U., Muendel, H. H., Chaudary, M. F., 1993. Effect of topping and rationing on seed yield and fodder production of rapeseed. (Brassica napus). Agron. Trend Agric. Sci. 1, 17-23.

Kokilavani, S., Jagannathan, R., Selvaraju, R., Thavaprakaash, N., 2007. Influence of terminal clipping on growth and yield of Sesame varieties. Asian J. Agric. Res. 1, 142-145.

Korla, B. N., Sani, A., 2003. Effect of date of sowing and cutting on seed yield of Fenugreek. Haryana J. Hortic. Sci. $32,120-122$.

Lewis, W. J., 2014. High Tunnel Crop Production Tips. Retrieved on April 28, 2016 from: https://sustainablefarming.rutgers.edu/wp-content/uploads/2014/09/HighTunnel-Crop-Production-Tips-by-Lewis-Jett-WVU.pdf

Maplandia, 2016. Iwollo-Oye. Retrieved on April 28, 2016 from: http://www.maplandia.com/nigeria/enugu/ezeagu/ iwollo-oye.

Okalebo, J. R., Gathua, K.W., Woomer, P. L., 2006. Laboratory Method of Soil Analysis: A Working Manual, $2^{\text {nd }}$ Edn. TSBR-CIAT and SACRED Africa, Nairobi, Kenya.

Okonmah, L. U., 2011. Effects of different types of staking and their cost effectiveness on the growth, yield and yield components of cucumber (Cucumis sativus L). Int. J. Agric. Sci. 1(5), 290-295.

Phu, N.T., 1997. Nitrogen and potassium effect on cucumber yield. AVI 1996 report, ARC/AVRDC Training Thailand.

Renner, S. S., Schaefer, H., Kocyan, A., 2007. Phylogenetics of Cucumis (Cucurbitaceae): Cucumber (C. sativus) belongs in an Asia/Autralian clade far from melon (C.melo). BMC Evol. Biol. 7, 58.

Singh, H., Diwakor, B., 1995. Chickpea Botany and Production Practices. ICRSAT. Skill Development Series No. 16.

Tindal, H. D., 1983. Vegetable Crops of the Lowland Tropics. Oxford University Press, Oxford. pp.101-125.

Uguru, M. I., 2011. Crop Production Tools, Techniques and Practices. Falladu Publishing Company, Nsukka. pp.55-58.

Venkadachalam, K., 2003. Response of sesame cultivars to crop geometry and clipping management in tail end of Cauvery delta zone. M.Sc. (Agric.) Thesis, Tamil Nadu Agricultural University, Coimbatore.

Vimala, P., Ting, C. C., Salbiah, H., Ibrahim, B., Ismail, L., 1999. Biomass production and nutrient yields of four green manures and their effects on the yield of cucumber. J. Trop. Agric. Food Sci. 27, 47-55.

Wells, O. S., Loy, J. B., 1993. Row covers and high tunnels enhance crop production in the Northeastern United States. Hort. Technol. 3, 94 (Abstr.).

\section{How to cite this article:}

Nwankwo, O. G., Adinde, J. O., Anieke, U. J., Ukwuani, C. M., Ugwuanyi, P. O., Aniakor, A. C., 2016. High tunnel production of cucumber (Cucumis sativus L.) as influenced by apical clipping in Iwollo, South Eastern Nigeria. Int. J. Curr. Res. Biosci. Plant Biol. 3(10), 1-6. doi: http://dx.doi.org/10.20546/ijcrbp.2016.310.001 